\begin{tabular}{|l|l|l|}
\hline \multicolumn{2}{|c|}{ PublisherInfo } \\
\hline \hline PublisherName & $:$ & BioMed Central \\
\hline \hline PublisherLocation & $:$ & London \\
\hline \hline PublisherImprintName & $:$ & BioMed Central \\
\hline \hline
\end{tabular}

\title{
Of ozone holes and Triffids
}

\begin{tabular}{||l|l|l||}
\hline \multicolumn{2}{|c|}{ ArticleInfo } \\
\hline \hline ArticleID & $:$ & 3724 \\
\hline \hline ArticleDOI & $:$ & $10.1186 /$ gb-spotlight-20000713-01 \\
\hline \hline ArticleCitationID & $:$ & spotlight-20000713-01 \\
\hline \hline ArticleSequenceNumber & $:$ & 161 \\
\hline \hline ArticleCategory & $:$ & Research news \\
\hline \hline ArticleFirstPage & $:$ & 1 \\
\hline \hline ArticleLastPage & $:$ & 2 \\
\hline \hline & & RegistrationDate : 2000-07-13 \\
ArticleHistory & $:$ & OnlineDate $\quad$ 2000-07-13 \\
\hline \hline ArticleCopyright & $:$ & BioMed Central Ltd2000 \\
\hline \hline ArticleGrants & $:$ & \\
\hline \hline ArticleContext & $:$ & 130591111 \\
\hline \hline
\end{tabular}




\section{William Wells}

Email: wells@biotext.com

Depletion of stratospheric ozone increases the amount of ultraviolet-B (UV-B) irradiation experienced on Earth. Now Ries et al. report in the 6 July Nature that increased UV-B exposure can reduce the genomic stability of plants (Nature 2000, 406:98-101). They use a reporter gene inserted as a tandem or inverted repeat as a probe to detect 1.7-fold to 14-fold increases in homologous recombination after increasing UV-B levels. The plant germline is protected from UV-B for much of its life, and yet the higher levels of UV-B also cause a 4-10-fold increase in germline recombination.

\section{References}

1. Increased summertime UV radiation in New Zealand in response to ozone loss.

2. Nature, [http://www.nature.com/nature/] 